\title{
Context and Linguistic Skills Factors Affecting the Pronunciation of Arabic Proper Names in Speakers of Bahdini Kurdish
}

\author{
Dilgash Mohammed Shareef* \\ University of Zakho, Zakho, Duhok, Kurdistan, Iraq \\ Corresponding Author: Dilgash Mohammed Shareef, E-mail: silevanayzaxo@gmail.com
}

\section{ARTICLE INFO}

\section{Article history}

Received: September 14, 2017

Accepted: November 03, 2017

Published: December 30, 2017

Volume: 8 Issue: 6

Advance access: December 2017

Conflicts of interest: None

Funding: None

\begin{abstract}
The purpose of this research is to explore the pronunciation of Arabic proper names by Bahdini Kurds living in Duhok and the districts around. Thirty-two respondents were selected to say fifty Arabic proper names commonly used by Kurdish today's society. The variables identified are linguistic skills in Kurdish and Arabic, and the extent of the formality of the context. The study concluded that being a fluent speaker of Arabic gives a Bahdini Kurdish speaker the ability to pronounce the Arabic proper names in a native-like accent. Yet, those speakers have revealed a tendency towards the use of a Kurdish pronunciation of such names when the context was informal. Dissimilarly, the Kurdish pronunciation was regularly used by speakers skilled or unskilled in Kurdish language and linguistics in both formal and informal situations.
\end{abstract}

Key words:

Proper Names,

Native Pronunciation,

Context,

Kurdish Pronunciation,

Bahdini-Kurdish,

Linguistic Skill

\section{INTRODUCTION}

\section{History of Arabic Names among Kurds}

Sadiq (2003:88) asserts that in the old times when the Kurdish nation was free, the names of the entire citizens were Kurdish [12].According to Kurdish folk tales and old writings some Kurdish names were: Swar (knight), Shivan (shepherd), Pirmam,Bapeer (grandfather), Meriwan, Brzo, Serdar, Memend, Ar (flour), Shirwan, Gul (rose) among many other names. But like other nations throughout history the Kurds have borrowed names from different cultures. In fact, non-Kurdish names are almost always present in Kurdish naming. Religious, political, ideological, westernization (immigration to the west), education, technology and media are all factors behind this phenomenon.

Islam contributed greatly to the spread of Arabic names among the Kurds who followed the new religion to the extent that their religious feelings became stronger than their feelings of nationalism. As a result, so many Arabic names began to be used and sometimes preferred on the account of purely Kurdish names. It is worth to mention, at this point, that Kurdish names did not make a noticeable appearance until after First World War (1914- 1919) when the Ottoman
Empire collapsed and the peoples of the Middle East asked for independence (Tawfiq and Hamad, 2006) and Murad (1984).

Until then, Arabic-Islamic names were prevalent and dominant among the Kurds because of the Islamic influence of the Ottoman rulers. However, some Kurdish names did appear from time to time. For example, Salahaddin Al- Euubi (1137- 1193), the famous Kurdish leader, had an uncle whose name was Sherko (a lion). When Kurds converted to Islam, the new religion had a radical effect on every aspect of their lifeand personal names were involved in that effect simply because names echo any change experienced by the people, Murad (1984). They found it honourable to name their children after religious figures such as those names of the Prophet Mohammed, Ahmed, Mahmood and Mustapha. Also, the ninety-nine attributes of Allah that begin with Abid (slave): Abdullah, Abdulqadir, Abdurrahman, Abdulkareem, etc. The names of the four Islamic caliphs; Abu Baker, Omer, Othman and Ali became preferable. Furthermore, names of non-Arab prophets mentioned in the Holy Quran were to be commonly used by Kurds such as Zakariya, Musa, Ismail, Isa (Jesus) and Yousif, etc. Thus, non-Arabic names were also borrowed under the influence of Islam. 
On the other hand, Sadiq (2003, pp. 87) has a different point of view. He believes that "Kurds named their children by Arabic names in the past and some of them nowadays because of unnecessary and harmful imposed traditions". This backward social phenomenon has been pursued due to non-understanding of the religion and low standard of culture and consciousness because according to him "God worship has nothing to do with naming of children by a certain language".

As for women, certain names were favoured especially those of the Prophet's wives and his daughters, Murad,1984. Such names are Fatima, Um-Kalthum, Roqayya and Zainab (the daughters of the Prophet), Khadija, Hafsa, Aisha (the wives of the Prophet), Amina (his mother),Halima (his foster mother).

During the late Islamic period Turkish and Mongolian names began to appear among the Kurds such as Dursan, Yashar, Turkan, Guzzle (which are Turkish), Taymur, and Jangiz (which are Mongolian), (ibid). The tendency towards such names was due to the weakness of the Islamic state at that time. On the other hand, during the reign of the Ottoman empire, the Kurds chose Arabic names that were used by the Turks and seemed as if they were Turkish such as Sa'adat (happiness), Ghurbat (Alienation), Raf'at (Highness),Hikmat (Wisdom), Fikrat (Thinking), Hidayat (Righteous), Shawkat (Fork)), Tala't (Appearance) and Najdat (Help), among many other names, Murad (1984).

Arabic-Islamic names remained dominant until after the First World War when such names began to be increasingly replaced by Kurdish names. It is worth to mention at this point that purely females Kurdish names preserved their "Kurdishness" more than male names. This is a point that needs more investigation as it has to do with socio-religious and political reasons, ibid.

After the uprising of 1991, Arabic Islamic names began appearing significantly instead of Kurdish names. On this occasion, the choice of such names was contemporary. That is to say, an Arabic name was the deliverer of the message or ideology of those Islamic parties and movements that appeared in Kurdistan in 1991. Such parties did not, or could not, regard the Kurdish national culture as their own and named their children accordingly choosing only Islamic names. As a result, new Arabic -Islamic names appeared in addition to the old ones, i.e. names of the prophet and the ninety nine attributes of Allah. Most of the new names are words taken from the Glorious Qur'an and were never used before as personal names. Such names are Risala, Thuha, Ilaaf, Marwa, Sidra, Madeena, Sumaya, Suhayb, among others.

\section{Current Arabic Names in Kurdish}

Nowadays, the Arabic proper names are not as often used as they were used in the early Islamic period due to reasons that might be related to the increase ofthe Kurds' nationality feelings and their increasingattachment to their Kurdishness. They started to realise that being a Muslim does not necessarily mean carrying a Muslim name and eventually an Arabic name. Therefore, Kurdish proper names have started to take over Arabic proper names. However, the three grand names of the Islam prophet (peace and blessings be upon him) are still commonly used by Kurdish today's society for religious and social ties reasons. One family, for example, may still name their child Ahmed, Mohammed or Mahmood because these are the names of the prophet Mohammed (peace and blessings be upon him). Another family may name their new-born baby after someone called Ahmed and lost to the family. Thus, Arabic proper names are registered every now and then among Kurdish people. It needs be mentioned that the majority of proper names selected for this research belong to people born in the middle of the twentieth century when Arabic names were more prevalently used among Kurds than in the twenty first century.

\section{Kurdish Language}

Kurdish belongs to the Indo-Iranian family of languages. It is a member of the north-western subgroups of the Iranian languages which are subdivisions of the Indo-Iranic branch of this largest family of languages in the world, Thakston (2006).

The area inhabited by Kurdish people as a similar community is called "Kurdistan" which means "nation of the Kurdish people". The boundaries of Kurdistan cannot be exactly identified because they do not co-occur with any international borders or inner administrative divisions. The Kurdish speech area is divided among five neighbouring countries which are Turkey, Iraq, Iran,Syria and Russia. It occupies north-western parts of Iran, south-eastern Turkey with overlaps into Russia, parts of north-eastern Syria and northern Iraq. The central governments of these countries do not provide any ethnic or linguistic maps to identify the Kurdish speech, Hasan (2012).

Furthermore, Kurdish has different writing systems. It is written in a modified Turkish Latin alphabet in Turkey, Syria and Europe. It is written in a modified Cyrillic script in the land of the Former Soviet Union (Armenia, Azerbaijan, Georgia and Kazakhstan) but it is written by the use of a modified Arabic alphabet in Iraq and Iran Ekici, 2007.

Concerning the current status of Kurdish, it has been declared the second official language in Iraq while it is banned in Syria and Turkey. In Iran, it is used in some local media and newspapers but not in schools, Hasan (2009).

With regard to Kurdish sound system, scholars seem to disagree on a unified classification of the Kurdish phonemic system, Marf (1976) and McCarus (1958).

The status of some sounds in Kurdish is controversial. For example, / $/$ / is a phoneme according to Marf (1976) whereas Ways (1984) does not regard the same sound a phoneme as it only appears at the beginning of vowel-initial words while the absence of $/ \mathrm{P} /$ in these words does not affect meaning, e.g / Ra: r/or/a: r/ both mean 'flour', Hasa (2012).

Additionally, there are sounds that have come to Kurdish as a result of language contact and therefore they act as regional allophones such as /ț h,, , y, q/ [13]. For instance, $/ \hbar /$ only appears as a regional variant in dialects of Kurdish that are affected by Arabic, Hasan (2009). The sound $/ \hbar /$ is realised differently in various dialects of Kurdish. It can be 
substituted by/h/in northern KurmanjiKurdish as in /hafte/-/ hafte/ 'eighty' or substituted by/S/in middle Kurmanji Kurdish as in /tahil/-/ta9 Il/'bitter'.

Another debatable sound in Kurdish is/ $/ \mathbf{s}^{\mathrm{f}} /$ which is also believed to have come from Arabic. For McCarus (1958), the sound is a phoneme in Sulaimani Kurdishand mainlyoccurs in Arabic loans as $/ \mathrm{s}^{\complement} \mathrm{a}$ : lih/“Salih' which is a muscular name. Interestingly, the sound is also available in Kurdish words as /s'a:1/“year',/s‘ $æ /{ }^{`} d o g$ ' (ibid).

Finally, it should be stated here that the status of purely Kurdish sounds remains unsolved and that separate future experimental studies need to identify purely Kurdish sounds. See appendixes A and B for vowel and consonant sounds in Kurdish based on Hasan (2012).

\section{Arabic Language}

Arabic is one of the world's major languages. It is the fifth most widely spoken language in the world and is second in terms of speakers, with over 250 million Arabic speakers, of whom roughly 195 million are first language speakers and fifty-five million are second language speakers.

Arabic has three forms: classical Arabic, modern standard Arabic and colloquial Arabic. Classical Arabic is the language of the Quran, the religious instruction in Islam and of the great writers and poets. Modern Standard Arabic(Al-Fusha') is one of the Arabic dialects and is the form of the Arabic language that is taught in schools and used in most radio and television broadcasts, formal talks, and the majority of the printed matter in the Arab world, including books. Colloquial Arabic or (Al-ammiyya) is the form of Arabic that is used in everyday oral communication, Al-Khatib (2003).

As far as the sound system of Arabic is concerned, there are twenty-nine consonants in Arabic as illustrated byBin-Muqbil, (2006). See appendix C for Arabic consonants.

As far as Arabic vowels are concerned, they are divided into two groups which are short vowels and long vowels. Modern standard Arabic has six vowels/a/,/i/,/u/and /a:/,/i:/,/u:/where the former three are short vowels and the latter three are the corresponding longer versions, Al-Ani (1970) and Al-Khatib, (2003). An Arabic diphthong, on the other hand, is a combination of a vowel and a consonant. There are two diphthongs in Arabic which are/aw/and/ay/. The glide in the first diphthong begins from the vowels/a/to the consonant/w/as in/nawm/2 'sleep'whereas the glide in the second diphthong starts from the vowel/a/to the consonant/y/as in/bayt/تيب 'house'.

Most problematic Arabic consonants for Kurdish speakers are/ $/ \theta /, / \mathrm{d} /, / \mathrm{z} /, / \mathrm{d} / \mathrm{and} / \mathrm{s} /$. . Therefore, a proper Arabic name containing any of these consonants is subject to have one of these sounds been replaced by equivalent Kurdish sounds when the name is used by a Kurdish speaker. Arabic speakers, on the other hand, struggle to pronounce Kurdish names

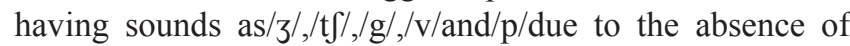
such sounds in standard Arabic.

\section{Research Aim and Hypotheses}

The aim of the current study is to shed light on the pronunciation of Arabic proper names by Bahdini speakers of
Kurdish with a particular emphasis on the role played by the context in a which a name is pronounced and also the Arabic and Kurdish linguistic skills of the users/speakers of an Arabic proper name. More specifically, it is hypothesized in the present study that most Arabic proper names used by the Bahdini Kurds are modified to suit the sound system of Kurdish language and that consonant sounds undergo the change more than vowel sounds do. It is also believed that the formality of the context increases a Bahdini Kurdish speaker's possibility to pronounce an Arabic name with a native-like pronunciation whereas a professional knowledge of Arabic increases a Kurdish speaker's likelihood to pronounce an Arabic proper name with a native-like pronunciation in formal and informal contexts.

\section{EARLIER STUDIES}

Murad (1984) provides a detailed account of Kurdish proper naming process starting from the pre-Islamic period, the Islamic era and the time following the late Islamic period (pp. 148-152). He mentions that different non-Kurdish proper names appeared among Kurds. In the pre-Islamic period, many Persian names were found among Kurds whereas Arabic and Islamic names were largely used by Kurds when they first converted to Islam and finally Mongolian and Turkish names were also seen among Kurds in the late Islamic period. Murad goes on to explain the different factors underlying the choice of a proper name for a new-born Kurdish baby and the customs and traditions accompanying the naming process. Interestingly, Murad adds that "during all these periods, Arabic-Islamic names underwent several morphological and phonological changes to suit the music of Kurdish" (p.152). Despite giving a good number of example names undergoing such changes, Murad does not systematically identify how and under what conditions phonological and morphological changes occur.

Albarany, Albamani and Shareef (2011) in their 'Kurdish Personal Names in Kurdistan of Iraq: A Sociolinguistic Perspective' examine Kurdish proper names within the perspective of sociolinguistics and anthropology with a particular emphasis on the factors underlying Kurdish personal naming process and the existence of non-Kurdish names among Kurds. Among such names, Arabic proper names were proved to be the most prominent foreign names among Kurdish people. There has not been, however, any reference as to how foreign names and eventually Arabic names have been pronounced by Kurds. For this purpose, the current study hopes to fill the gap in this area by concentration on how Arabic proper names are pronounced by Kurdish people with different linguistic skills in Arabic and Kurdish in different contexts.

\section{PARTICIPANTS}

Thirty-two native speakers of Bahdini Kurdish participated in this study. They were all residents of Duhok city located in Northern Iraq.Four faculty members employed in teaching Kurdish language and linguistics at Zakho University and whose mother language is Kurdish were selected to say the 
names and, thus, they were skilled in Kurdish language and linguistics. Other four faculty members at Zakho University trained in teaching Arabic language and literature whose mother tongue is also Kurdish were asked to say the names chosen for the current study.

The purpose behind selecting people skilled in Kurdish and Arabic languages was to examine if a speaker's educational and skilled knowledge of either languages would have any effect on the pronunciation of Arabic proper names repeatedly found among Bahdini Kurds.

The rest of the subjects were faculty members and administrative employees at Zakho University lacking such linguistic skill and training. The age range of the participants rangeed between 25-50 and the rate of men and women among them was nearly equal.

\section{DATA COLLECTION METHODOLOGY}

Fifty original Arabic proper names were chosen for this study.The emphasis has largely been on names that are difficult for Kurdish speakers to pronounce without making some phonological changes. The names selected vary between those ending in tầ- marbūtah and hamza, having geminates or consonants not existed in Kurdish. The Kurdish pronunciation of each name is given and after that the native Arabic pronunciation is provided in order to reveal the differences of pronunciations. The names were distributed to all participants who had demonstrated interest in participating in the research and they all pronounced the names.

\section{RESULTS AND DISCUSSION}

Participants trained in teaching Arabic language at Zakho University stated that their skilled knowledge of Arabic and accordingly the features of its sound system hasenabled them to acquire a native-like pronunciation of whichever Arabic proper name. They also added that when reading aloud students' names in a universityclassroom; they follow the Arabic pronunciation of an Arabic proper name whereas the Arabic name of a person in an informal context can possibly be pronounced by those teachers after the Kurdish pronunciation.

One teacher, participating in this study, pointed out that he will call a student named 'Zarah' after the Arabic pronunciation [zæhræ] but when he is at home, he willcall his daughter whose name is also 'Zahra' after the Kurdish pronunciation[zæhra: ]. These pronunciation differences go back to the different contexts in which the names are called. The context and the teacher-student relation are both formal in a University classroom while they are informal at home with a father-daughter relation. Table (1) includes two main pronunciations of a list of Arabic proper names ending in Tâ' marbūtahused by Arabic language teachers at Zakho University, henceforth the Arabic pronunciation is (AP) and the Kurdish pronunciation is (KP):

Another possible reason behind such pronunciation differences could be related withthe effect of the mother tongue. The teacher in the example mentioned is not always able to detach the sound system and orthographic features of Kurdish language from his Arabic pronunciation.Tā' marbūțah at the end of the name 'zahra' is pronounced as [æ] when the name is used by native speakers of Arabic while it commonly corresponds to /a:/ vowel when the name is used and pronounced by Bahdini Kurdish speakers. The change of the final vowel can possibly be related with the different orthographic systems of Arabic and Kurdish since the latter does not have Tà' marbūțh as a letter.

Similar to names ending in tā'-marbūțah, names ending in hamza / $/$ / were pronounced. With formal contexts and relations, the Hamza $/ 2 /$ sound was pronounced whereas the sound is silent in an informal context as the latter pronunciation is more common among the majority of Kurds. Below is Table (2) containing these variable pronunciations.

Table 1. Names ending in tā' marbūțah as pronounced by Arabic Language Teachers

\begin{tabular}{|c|c|c|c|}
\hline No & $\begin{array}{l}\text { Names ending } \\
\text { in tā'__marbūțah }\end{array}$ & $\begin{array}{l}\text { AP/Formal } \\
\text { Context }\end{array}$ & $\begin{array}{l}\text { KP/Informal } \\
\text { Context }\end{array}$ \\
\hline 1 & 'zahra' & [zæhræ] & [zæhræ] \\
\hline 2 & 'mā'da' & [ma:Pdæ] & [ma:Pdæ] \\
\hline 3 & 'mājīda' & [ma:dzidæ] & [ma:dzidæ] \\
\hline 4 & 'wājīda' & [wa:dzidæ] & [wa:dzidæ] \\
\hline 5 & 'zāhīda' & [za:hidæ] & [za:hidæ] \\
\hline 6 & 'madīna' & [mædi:næ] & [mædi:næ] \\
\hline 7 & 'Samsha' & [Samfæ] & [Yamfæ] \\
\hline 8 & 'khālīda' & 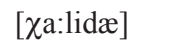 & 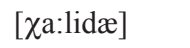 \\
\hline 9 & 'walīda' & [wælidæ] & [wælidæ] \\
\hline 10 & 'jamīla' & [dzæmi:læ] & [dzæmi:læ] \\
\hline 11 & 'nāhīda' & [na:hidæ] & [na:hidæ] \\
\hline 12 & 'fatīha' & [fati:ћæ] & [fati:ћæ] \\
\hline 13 & 'ruqayya' & [ruqajjæ] & /ræqja:/ \\
\hline 14 & 'Caqlīma' & [؟æqli:mæ] & [؟æqli:mæ] \\
\hline 15 & 'făț̄ima' & [fa:țimæ] & [fa:timæ] \\
\hline 16 & 'khawla' & [xawlæ] & [xawlæ] \\
\hline 17 & 'halīma' & [ћæli:mæ] & [ћæli:mæ] \\
\hline 28 & 'shukrīyya' & [ Jukrijæ] & [ okrijæ] \\
\hline 19 & 'gharībā' & [вæri: bæ] & [вæri: bæ] \\
\hline
\end{tabular}

Table 2. Names ending in hamza as pronounced by Arabic language teachers

\begin{tabular}{|c|c|c|c|}
\hline No & Proper Names & $\begin{array}{l}\text { AP/Formal } \\
\text { Context }\end{array}$ & $\begin{array}{l}\text { KP/Informal } \\
\text { Context }\end{array}$ \\
\hline 1 & 'du' ā?' & [duSa:?] & [duSa:] \\
\hline 2 & 'hayf ā?' & [hayfa:?] & [hayfa:] \\
\hline 3 & 'majl ā?' & [nadzla:?] & [nadzla:] \\
\hline 4 & 'ḥamrā?' & [ћamra:?] & [ћamra:] \\
\hline 5 & 'baydā?' & [bayda:?] & [bayda:] \\
\hline 6 & 'fayḥā?' & [fayћa:?] & [fayћa:] \\
\hline 7 & 'juwayr ā?' & [dzowerra:?] & [dzowerra:] \\
\hline 8 & 'zahrā?' & [zahra:?] & [zahra:] \\
\hline 9 & 'asmā?' & [asma:?] & [asma:] \\
\hline 10 & 'șafā?' & [șafa:?] & [șafa:] \\
\hline
\end{tabular}


It has also been revealed that geminate consonants have properly been pronounced by Arabic language teacher's due to the effect of their awareness of Arabic language pronunciation. The vast majority of Allah names carrying geminates are pronounced following the Arabic pronunciation except in few informal contexts in which there is a higher possibility for a Kurdish pronunciation to arise. In such a case, geminated consonants are degeminated. Some examples are available in Table (3):

The participants employed to teach Kurdish as a first language at Zakho University confirmed that their skilled knowledge of Kurdish language has no effect whatsoever on their pronunciation of Arabic proper names and that they, unlike Arabic language teachers, will more likely pronounce the names with a foreign accent, i.e. Kurdish accent regardless of the context. For this reason, the results of the remaining participants who were faculty members and administrative employees at Zakho University were similar to the results obtained from Kurdish language teachers. Thus, Arabic proper names ending in tâ' marbūțah or hamza were pronounced by those teachers, faculty members and administrative employees following the Kurdish pronunciation irrespective of the formality of the contexts in which the names were used in. In other words, tā' marbūtah is pronounced as /a:/ while hamza is realized as a zero sound at the end of Arabic proper names. The reason why hamza sound is silent is because the sound in question does not exist in Kurdish phonemic system. Therefore, Kurdish people who are not aware of the Arabic sound system or who do not speak the Arabic language would more likely leave out hamza / / / when uttering a name ending in it.The same goes for names having hamza in the middle as in "مّلدئام" "مان" The first name is pronounced /na:Pilæ/ by Arab speakers and the second as /ma:?idæ/ whereas the hamza sound in the middle of these two names is not pronounced by the majority of Kurds and accordingly these names are pronounced as [na: ila:] \& [ma: ida:] respectively.

There are, however, some exceptional names that are pronounced in a somewhat Arabic-like pronunciation when anon-Arabic language speaker participatingin this study pronouncescertain names in a formal situation. Table (4) shows any possible pronunciations of some Arabic proper names by a Kurdish language teacher in two different contexts, i.e. formal and informal contexts:

It needs to be mentioned that several Arabic proper names have been noticed to have two different informal pronunciations with one pronunciation being more informal than the other. The more informal pronunciation of such names is characterised by having two or more sounds changed. The $\mathrm{KP}$ in the first column in Table (5) is more formal than the $\mathrm{KP}$ in the second column:

Participants skilled in Kurdish language and linguistics and those lacking this skill have similarly pronounced Arabic proper names carrying geminate consonants. Both groups confirmed that they would generally degeminate consonants found in an Arabic proper name. The phonological justification behind this process is perhaps related with the nonexistence of geminate consonants in Kurdish. It has been noticed, however, that many participants have not always degeminated consonants in an Arabic proper name. For example, geminate consonants in several Allah names have correctly been pronounced by those same participants who would degeminate consonants in other names, see Table (6)

Table 3. Allah names containing geminates as pronounced by Arabic language teachers

\begin{tabular}{|c|c|c|c|}
\hline No & Allah Names & $\begin{array}{l}\text { AP/Formal } \\
\text { Context }\end{array}$ & $\begin{array}{l}\text { KP/Informal } \\
\text { Context }\end{array}$ \\
\hline 1 & 'fattāḥ' & [fætta: $\hbar]$ & [fæta: $\hbar$ ] \\
\hline 2 & 'ghaffār' & [вæffa:r] & [вæfa:r] \\
\hline 3 & ‘qahhār' & [qahha:r] & [qaha:r] \\
\hline 4 & 'sattār' & [sætta:r] & [sæta:r] \\
\hline 5 & 'wahhāb' & [wæhha:b] & [wæha:b] \\
\hline 6 & ‘jabbār' & [d]æbba: r] & [dzæba: r] \\
\hline
\end{tabular}

Table 4. Pronunciations of some Arabic proper names by Kurdish language teachers and administrative employees at Zakho University

\begin{tabular}{|c|c|c|c|}
\hline No & $\begin{array}{l}\text { Arabic } \\
\text { Proper Names }\end{array}$ & $\begin{array}{l}\text { AP/Formal } \\
\text { Context }\end{array}$ & $\begin{array}{l}\text { KP/Informal } \\
\text { Context }\end{array}$ \\
\hline 1 & ' 'mar' & [Somær] & [Gæmær] \\
\hline 2 & ‘ībrāhīm’ & [ibra:hi:m] & $\begin{array}{l}\text { [bræhi:m] } \\
\text { or [bra:hi:m] }\end{array}$ \\
\hline 3 & 'īsmā'l' & [isma:Yi:1] & $\begin{array}{l}\text { [sma:Yi:1] } \\
\text { or[sma:yi:1] }\end{array}$ \\
\hline 4 & 'musā' & /mosa:] & [mi:sa:] \\
\hline 5 & 'yūsūf' & [ju:sif] & [i:sif] \\
\hline 6 & ‘jūnis' & [ju: nis] & [i: nis] \\
\hline
\end{tabular}

Table 5. Two informal pronunciations of Arabic proper names as pronounced by non-Arabic language participants

\begin{tabular}{|c|c|c|c|}
\hline No & $\begin{array}{l}\text { Ending in tā' } \\
\text { marbūṭah } \\
\text { Names }\end{array}$ & $\begin{array}{l}\text { KP/Formal } \\
\text { Context }\end{array}$ & $\begin{array}{l}\text { KP/Informal } \\
\text { Context }\end{array}$ \\
\hline 1 & 'nā'la' & [na:Pla:] & [na:ila:] \\
\hline 2 & 'fāțīma' & [fa:țma:] & [fa:țe] or [fa:lma:] \\
\hline 3 & 'Cā’sha' & 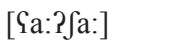 & [ৎæy \\
\hline 4 & 'mā'da' & [ma:?da:] & [ma:ida:] \\
\hline 5 & 'Cothmān' & [Sosma: $\mathrm{n}$ ] & [osma: $\mathrm{n}$ ] \\
\hline
\end{tabular}

Table 6. Degeminaion as pronounced by Kurdish language teachers and Zakho University employees

\begin{tabular}{llll}
\hline No & Arabic Proper Name & AP & KP \\
\hline 1 & 'mohammad” & [moћæmmad] & [mћæmæd] \\
2 & 'șddīq' & [șddi:q] & [sædi:q] \\
4 & 'roqayya' & [ruqayya] & [ræqja:] \\
5 & 'shokryya' & [Jukrijja] & [Jkrija:] \\
\hline
\end{tabular}


Table 7. Replacement of $/ \mathrm{d}^{\mathrm{s} /} / \mathrm{s}^{\mathrm{s} / / \theta / b y / z /, / s} /$ by Kurdish language teachers and administrative employees

\begin{tabular}{|c|c|c|c|}
\hline No & Arabic Proper Name & $\mathbf{A P}$ & $\mathbf{K P}$ \\
\hline 1 & ‘'othmān’ & [ & $\begin{array}{l}\text { [ } \text { fosma:n] } \\
\text { or [osma:n] }\end{array}$ \\
\hline 2 & 'ryāḍ’ & {$\left[\right.$ rja: $\left.d^{\mathrm{C}}\right]$} & [rja: $]$ \\
\hline 3 & 'șadq & [șddi:q] & [sædi:q] \\
\hline 4 & ‘ramad̦ān' & [ræmæd'a:n] & [ræmæza:n \\
\hline 5 & ‘șalāh’ & [șala:ћ] & [sala:h] \\
\hline 6 & 'șabāḥ’' & [șaba:ћ] & [saba: $\hbar]$ \\
\hline
\end{tabular}

for consonant degemination made by Kurdish language teachers and Zakho University administrative employees:

The irregularity of consonant degemination can be traced back to the way the participants have heard the name from the person who carries the name. For several participants, they would pronounce a name the way they perceive it form the holder of the name himself/herself and, thus, if a proper name was first heard with the geminated consonants been kept, then it is likely that users of the name will pronounce the geminate consonants. This can be true for the participants of the current research because all of them are educated and they have had some contact with Arabic language either through high school Arabic classes or through communication with Arab natives. From the researcher's perspective, illiterate and uneducated people will always degeminate consonants irrespective of the way they hear the name first time and this is because they are only skilled in the phonological features of their mother tongue and they will find it hard to train their tongues on phonological aspects of foreign languages especially when the native and the foreign language belong to different language families.

It has, however, been noticed that several Arabic proper names containing geminates have almost always been pronounced without geminates regardless of the formality of the context or the way the name is first time heard. In fact, the Kurdish pronunciations (KP) mentioned in Table (6) are the common pronunciations among Bahdiny Kurds though the proper name 'șddīq' gives two totally unrelated meanings when the second sound/d/is geminated or degeminated. With a geminated/d/the name is used as a proper name to mean 'being honest' while degeminting/d/gives the meaning of 'friend' in Arabic and is not usually used as a name of a person among Kurds and Arabs as well.

It is worth referring to that participants skilled in Kurdish language teachers and administrative employees who took part in this study would generally replace sounds as $/ \mathrm{d}^{\mathrm{S}} / / \mathrm{s}^{\mathrm{s}} /$ and $/ \theta / b y / z /, / s / a n d / s /$ respectively due to the absence of such sounds in Kurdish, see Table 7.

\section{CONCLUSIONS}

In this article, the pronunciation of Arabic proper names by speakers of Bahdini Kurdish has been examined with reference to the possible role played by the context in which a name is pronounced and the linguistic skill of the speaker of the name. Interestingly, this research has revealed a number of points.

Firstly, it was found that a Kurdish speaker's professional knowledge of Arabic language and linguistics can significantly improve his/her pronunciation of any Arabic proper names but this linguistic ability has shown to be context-bound due to reasons related to the effect of the mother tongue and the formality of the relationship between the interlocutors,i.e. the Arabic pronunciation is only used in an informal situation.

Secondly, it was revealed that whether or not a speaker is skilled in Kurdish language and linguistics, s/he has similar pronunciations of Arabic proper names. They generally degeminate consonants, pronounce Tā marbūtah at the end of Arabic proper names as /a:/, leave out Hamza / $/$ / sound at the end of names, and sometimes replace $/ \mathrm{s}^{\mathrm{s}} / \mathrm{with} / \mathrm{s} /$ in few Arabic proper names. Thus, knowledge of Kurdish language and linguistics did not seem to have affected the pronunciation performances of Arabic proper names by Kurdish speakers. Finally, with these groups of speakers, context did not seem to have a major role on the use of a particular pronunciation.

\section{REFERENCES}

Al-Ani, S. (1970). Arabic Phonology: An Acoustic and Physiologicatial Investigation. The Hague: Mouton.

Albarany, L., Albamarni,A., and Shareef, D. (2011). Kurdish Personal Names in Kurdistan of Iraq: A Sociolinguistic Perspective.

Al-Khatib, S. (2003). The Formal Notation of Some Phonological Processes in the Holy Quran, JKAU: Edu.Sci.

Bin-Muqbil, M. (2006). Phonetic and Phonological Aspects of Arabic Emphatics and Gutturals. $\mathrm{PhD}$ dissertation. University of Wisconsin-Madison.

Ekici, D. (2007). Kurmanji Kurdish Reader. United States of America.: Dunwoody press. Retrieved on 20/4/2015 from www.//kurdipedia.org

Hasan, A.M. (2009). Consonant Clusters in the Northern Kururmanji Kurdish. Journal of Duhok University, 12, 1, 1-8.

Hasan, A.M. (2012). Kurdish Intonation with Reference to English. Unpublished $\mathrm{PhD}$ dissertation. University of Ulster.

Khoshnaw, N,A. (2014). Dangsazi (Phonetics). $2^{\text {nd }}$ ed. Hawler. Hevi press.

Marf, A. (1976). Zimanî kurdî libar ro fonetîkda (Kurdish language in phonetics). Baghdad: Zanyari Kurdi Press.

McCarus, E.N.(1958). Kurdish Grammar.Descriptive Analysis of the Kurdish of Sulaimaniya. New York: American Council of Learned Societies.

Murad, A.K. (1984). Asma' al-Nās: Ma' ānīha wa Asbāb al-Tasmya Bìha. 'People's Names: Their Meanings and Reasons behind them'. Baghdad: Dar Al-Hurrya.

Sadiq, Fuad Tahir.(2003).The Kurdish Culture: Some Samples and Brief Descriptions. Kurdistan -Sulaimani.

Thakston,W.M. (2006). Kurmanji Kurdish.Cambridge, Mass. Harvard University. Retrieved 8/4/2015 from www.//fas. Harvard.edu//.

Ways, G.F. (1984). Fonatic (Phonetics). Baghdad. Al-Adab Press. 


\section{APPENDIXS}

Appendix A: Kurdish Consonant Phonemes from Hasan (2012)

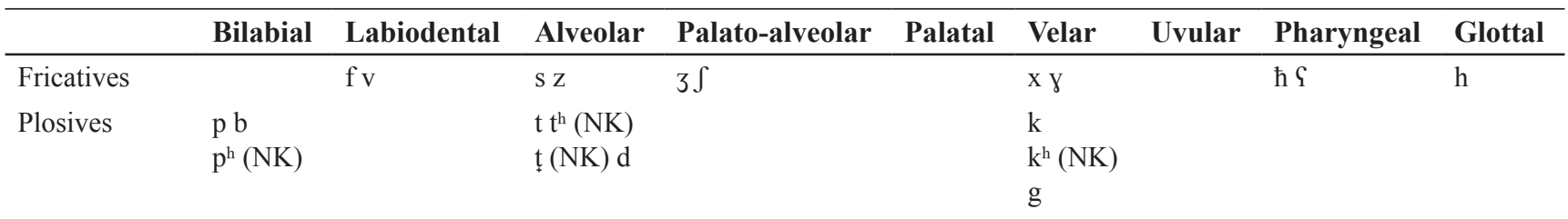

Affricates

$\operatorname{tg}^{\mathrm{th}}(\mathrm{NK}) \mathrm{dt}$

$\begin{array}{lll}\text { Nasals } & \mathrm{m} & \mathrm{n} \\ \text { Flaps } & & \mathrm{f} \\ \text { Trills } & & \mathrm{r}\end{array}$

Laterals $\quad$ ll(MK)

Approximants W J

Appendix B: Kurdish Vowel Phonemes from Hasan (2012)

\begin{tabular}{|c|c|c|c|}
\hline & Front & Central & Back \\
\hline Close & $\mathrm{i}: \mathrm{i}$ & & $\mathrm{u}$ \\
\hline Mid-close & e: & & o \\
\hline Mid-open & $\mathrm{a}$ & & \\
\hline Open & & & $\mathrm{a}:$ \\
\hline
\end{tabular}

Appendix C: Kurdish Transliteration System

\begin{tabular}{|c|c|c|c|c|c|}
\hline \multirow[t]{2}{*}{ Arabic } & \multicolumn{2}{|c|}{ NK Latin } & \multirow[t]{2}{*}{ Sound IPA } & \multirow[t]{2}{*}{ Example } & \multirow[t]{2}{*}{ Meaning } \\
\hline & Capital & Small & & & \\
\hline 1 & $\mathrm{~A}$ & $\mathrm{a}$ & /a:/ & av & Water \\
\hline ب & $\mathrm{B}$ & $\mathrm{b}$ & $/ \mathrm{b} /$ & bîr & Well \\
\hline 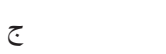 & $\mathrm{C}$ & $\mathrm{c}$ & $/ d z /$ & can & Beautiful \\
\hline ] & Ç & ç & $/ \mathfrak{t}$ & çav & Eye \\
\hline د & $\mathrm{D}$ & $\mathrm{d}$ & $/ \mathrm{d} /$ & dar & Tree \\
\hline 。 & $\mathrm{E}$ & $\mathrm{e}$ & $/ \mathrm{a} /$ & ez & I \\
\hline ى & $\hat{\mathrm{E}}$ & $\hat{\mathrm{e}}$ & /e:/ & êvar & Evening \\
\hline ف & $\mathrm{F}$ & $\mathrm{f}$ & $/ \mathrm{f} /$ & freh & Wide \\
\hline 3 & G & $\mathrm{g}$ & /g/ & germ & Hot \\
\hline$ه$ & $\mathrm{H}$ & $\mathrm{h}$ & $/ \mathrm{h} /$ & helat & Sunrise \\
\hline$\tau$ & $\ddot{\mathrm{H}}$ & $\ddot{\mathrm{h}}$ & $/ \hbar /$ & ḧemîd & name of a person \\
\hline ي & Î & $\hat{\imath}$ & /i:/ & îmarat & Emirates \\
\hline Not written & I & i & /i/ & dil & Heart \\
\hline j & $\mathrm{J}$ & $\mathrm{j}$ & $|3|$ & jiyan & Life \\
\hline ك & $\mathrm{K}$ & $\mathrm{k}$ & $/ \mathrm{k} /$ & kew & Dove \\
\hline J & $\mathrm{L}$ & 1 & $/ 1 /$ & leş & Body \\
\hline J & $\mathrm{L}^{\prime}$ & 1 ' & $/ 1 /$ & sal' & Year \\
\hline s & M & $\mathrm{m}$ & $/ \mathrm{m} /$ & mam & Uncle \\
\hline ن & $\mathrm{N}$ & $\mathrm{n}$ & $/ \mathrm{n} /$ & nan & Bread \\
\hline و & $\mathrm{O}$ & o & /o/ & roj & Day \\
\hline 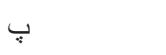 & $\mathrm{P}$ & $\mathrm{p}$ & $/ \mathrm{p} /$ & pîr & Old \\
\hline ق & Q & $\mathrm{q}$ & $\mathrm{q} /$ & qela & Castle \\
\hline
\end{tabular}


Appendix C: (Continued...)

\begin{tabular}{|c|c|c|c|c|c|}
\hline \multirow[t]{2}{*}{ Arabic } & \multicolumn{2}{|c|}{ NK Latin } & \multirow[t]{2}{*}{ Sound IPA } & \multirow[t]{2}{*}{ Example } & \multirow[t]{2}{*}{ Meaning } \\
\hline & Capital & Small & & & \\
\hline$J$ & $\mathrm{R}$ & $\mathrm{r}$ & $\mid \mathrm{f} /$ & bira & Brother \\
\hline 2 & $\mathrm{R}^{\prime}$ & $\mathrm{r}^{\prime}$ & $/ \mathrm{r} /$ & r'ast & Right \\
\hline س س & $\mathrm{S}$ & s & $/ \mathrm{s} /$ & ser & Head \\
\hline ش & Ş & Ş & $/ \mathrm{g} /$ & şans & Luck \\
\hline b & T⿱ & ț & $/ \mathrm{t} /$ & ța & Branch \\
\hline$ت$ & $\mathrm{~T}$ & $\mathrm{t}$ & $/ \mathrm{t} /$ & te & You \\
\hline g & $\mathrm{U}$ & $\mathrm{u}$ & $/ \mathrm{u} /$ & kurd & Kurd \\
\hline وو & $\hat{U}$ & û & /u:/ & bûn & Birth \\
\hline ث & $\mathrm{V}$ & $\mathrm{v}$ & $/ \mathrm{v} /$ & yiyan & Love \\
\hline و & W & $\mathrm{w}$ & $/ \mathrm{w} /$ & war & Home \\
\hline$\dot{\tau}$ & $\mathrm{X}$ & $\mathrm{x}$ & $/ \mathrm{x} /$ & xelk & People \\
\hline$\dot{\varepsilon}$ & $\ddot{X}$ & $\ddot{\mathrm{x}}$ & $/ \mathrm{y} /$ & ẍem & sadness \\
\hline ي & $\mathrm{Y}$ & $\mathrm{y}$ & $/ \mathrm{j} /$ & yar & Beloved \\
\hline j & $\mathrm{Z}$ & $\mathrm{z}$ & $|z|$ & zer & Yellow \\
\hline$\varepsilon$ & $E^{\prime}$ & $\mathrm{e}^{\prime}$ & $/ \mathrm{G} /$ & e'rd & Land \\
\hline
\end{tabular}

Appendix C: Arabic Alphabetical System

\begin{tabular}{|c|c|c|c|}
\hline $\begin{array}{l}\text { Arabic } \\
\text { Character }\end{array}$ & Letter Name & Example & Meaning \\
\hline I (a) & a-lif & ' اب 'ab' & father \\
\hline (b) & bah & باب ‘bāb’ & door \\
\hline$ت(t)$ & tah & تلميذ 'tilmīdh' & student \\
\hline$ث($ th $)$ & thah & ثلاثة 'thalātha' & three \\
\hline ج (j) & jīm & جميل 'jamīll' & pretty \\
\hline ح (h) & ḩah & حر 'har’ & hot \\
\hline$\dot{\tau}(\mathrm{kh})$ & khah & خوخ 'khawkh' & peach \\
\hline s(d) & dāl & 'dār’ دار ' & house \\
\hline$\dot{j}(\mathrm{dh})$ & dhāl & ذهب ‘dhahab’ & gold \\
\hline$J(r)$ & rā' & 'rajul' رجل ' & $\operatorname{man}$ \\
\hline$j(z)$ & zāy & 'zawjah' زوجة ' & wife \\
\hline (s) س (s) & sīn & سمك 'samak' & fish \\
\hline ش (sh) & shīn & 'shams' شمس 's & sun \\
\hline (ș) ص & șād & صديق 'șadīq' & friend \\
\hline (d) ض & d̦ād & ضباب ‘ḍabāb’' & fog \\
\hline$b(t)$ & țầ & 'țabīb’ & doctor \\
\hline ظ(z) & ża & ظهر 'zahr' & back \\
\hline$\varepsilon(')$ & 'ayn & 'īraq’' ، عراق ' & Iraq \\
\hline$\dot{\varepsilon}(\mathrm{gh})$ & ghayn & غريب 'gharīb' & foreign \\
\hline ق (q) & oāf & 'qahwa' قهوة ' & coffee \\
\hline s (k) & kāf & 'kutub' كتب 'k & books \\
\hline J(1) & lām & لكن 'lākn' & but \\
\hline م (m) & Mīm & 'makhzan’ مخزن ‘ & store \\
\hline ن (n) & nūn & نظيف 'naz̄if' & clean \\
\hline •(h) & hā' & هو 'huwa' & he \\
\hline $9(w)$ & wāw & wazīr وزير & minister \\
\hline ي (y) & yā' & نيمي yamīn’ & right \\
\hline
\end{tabular}

